\title{
人間工学1.0〜 IoT時代における身体計測とスマートデザイン
}

\author{
○後藤泰徳, 平田一郎（兵庫県立工業技術センター） \\ Ergonomics1.0 Anthropometry and Smart Design in the IoT \\ Yasunori GOTO, Ichiro HIRATA (Hyogo Prefectural Institute of Technology)
}

\section{1.はじめに}

本研究は平成26年度より開発中の「個人向けの テーラメードランニングシューズの設計・生産シ ステム (SIP/戦略的イノベーション創造プログラ ム）の一環である。ユーザのスマートフォンカメ ラ機能と各種センサを活用したアプリから身体形 状データを取得し、サーバに送信する。サーバ上 の自動三次元形状生成アルゴリズムによって生成 した身体形状に基づき、デザインしたカスタムメ イド製品を提供するシステムである。前回の日本 人間工学会第 57 回大会において、「スマートフォ ンアプリを活用したユーザ足形状に関する情報収 集システム」と題し、ユーザのスマートフォンカ メラ機能と各種センサを活用した足計測アプリに より、足の各部位寸法を画像処理によって取得す る方法について発表した。今回はこの足計測アプ リによって、得られたデータからユーザにあった ランニングシューズを選択できるように開発した アプリについて発表する。

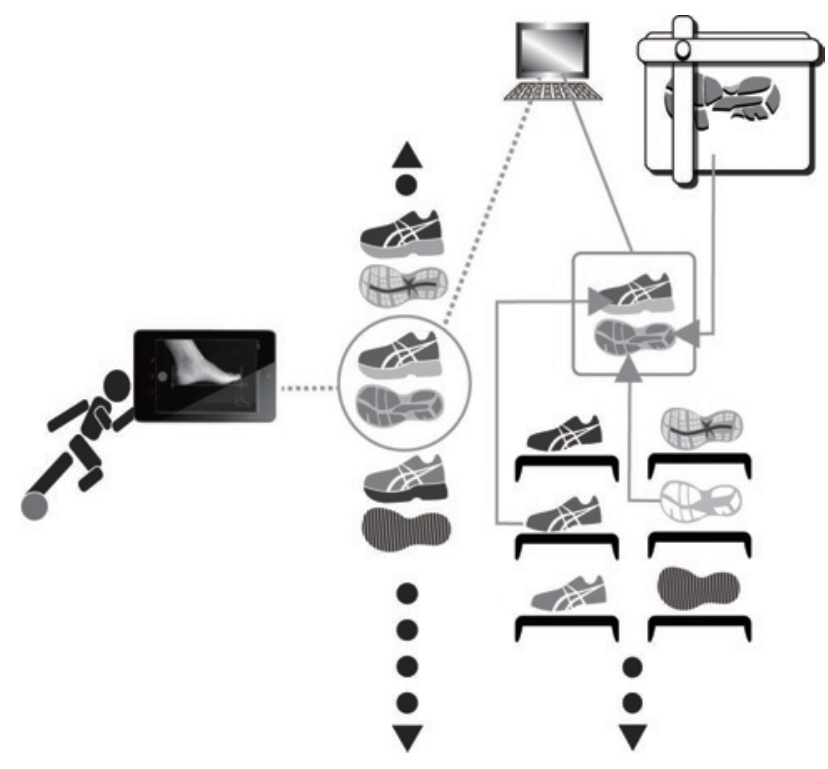

図1 システム全体メージ

\section{2．スマートフォンによる足計測}

まず、すでに開発済夕足計測アプリについて説 明する。このアプリを使用することで、ユーザは 自分で足の計測を行うことが可能である。現在ま でに測定可能な計測箇所は(1)足長、(2)足幅、(3)足 高、(4)アーチ高、(5)第一趾側角度、(6)踵の傾き (プロネーション角度) とした。開発用に使用し たスマートフォンは SONY Xperia Z2( 画面サイ ズ: $1920 \times 1080$ ピクセル.OS : Android 5.0.1) である。また、(1)足長、(2)足幅、(3)足高、(4)アー チ高については、スマートフォンに内蔵されてい る各種センサや画像処理機能を複合的に活用した 自動計測方式である。計測部位毎にナビゲーショ ンに従って足の各部位を撮影すると、それぞれの 計測部位を即時に自動計算し、表示する仕組みに なっている。(5)第一趾側角度、6)踵の傾き測定は、 ユーザがスマートフォンのカメラ機能を使って

（前後面使用可）、自ら足部後方画像を撮影した 後、足の画像写真上に自動表示されるインジケー タを操作してもらうことにより自動表示寸る仕組 みになっている。

\section{3 、ネットワーク環境構築}

以上は、前回発表したスマートフォン活用によ る足計測の概要である。今回は、この足計測デー タを活用してスマートフォンユーザでもあるラン ナーが自分にあったランニングシューズを選択・ 注文できるューズ選択アプリを開発した。このア プリ開発にあたり、通信環境の構築が必要となる。 そこで、まずスマートフォンとサーバによって構 成される通信ネットワーク環境を構築した。これ により、「スマホで足計測 $\rightarrow$ 通信アプリでホス

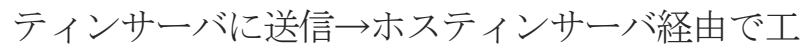
業技術センターのローカルサーバ上で必要な処理 一逆経路で結果をスマートフォンに送信」ができ るようにした。 


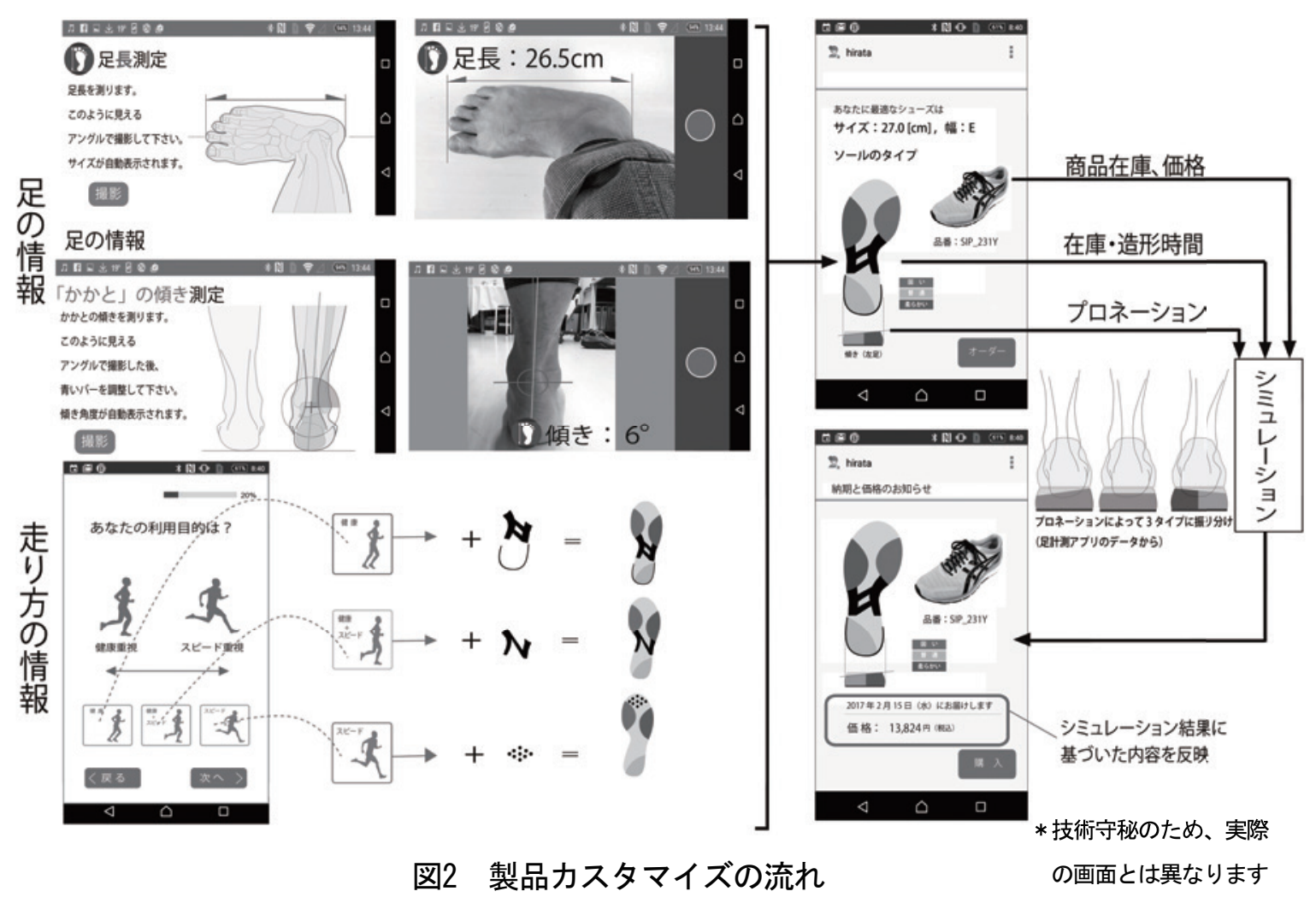

\section{4. 測定データから製品カスタマイズ}

ランニングシューズ選択アプリでは、「足の情 報」収集に加え、「走り方の情報」収集もできる ようにしている。「足の情報」収集=デジタルカ メラによる写真画像の活用により得られた足長・ 足巾などのデータにもとづき、アプリ上で測定寸 法に該当するサイズを自動的に選定（=グレー ディング）されるようになっている。また、踵の 画像写真から得られた踵の倒れ角度（=プロネー ション）によってもオーバー、ノーマル、アン ダーの3種類のシューズのいずれか適合するタイ プに選別される。「走り方の情報」収集では、ラ ンニング時の着地方法（踵か?つま先か?）、歩 幅（大きい?小さい?）によってソールを選択す るメニュー項目を設けた。また、快適に走ること を目的にするのか、スピード重視にするかでも選 択できるようになっている。さらに、路面の種類 （舗装路、地面、トラック）によっても選択でき るようになっている。アッパーに関してはカラー (5色)のみの選択にしている。

以上の項目は、現実に販売されているシューズ を想定して作られたものではではなく、あくまで もネットを活用してシューズ購入の可能性を示し た一つの試案である。

\section{5. 終わりに}

IoT時代になり、活動量計をはじめとするウェ アラブル型装置が普及し、人間の身体情報取得は 実験室から日常生活環境へとステージを移しつつ ある。また、それらの情報はデジタル化・DB化・ ネットワーク化しつつある。今回の研究は、 シューズという製品分野において、特定のラボや 店舗で行われていた身体計測をスマートフォンに 代用させることで、身体情報をIoTとつなげ、足 への機能的適合サービスを提供する一つの試案で ある。このような試みは今後、物理的な身体情報 がデータベースとして蓄積し、さらに指向や好み といった他の価值情報と関連づけされることで、 スマート社会を寄り現実感のあるものとし、さら なるパーソナルな製品デザインやサービスが可能 にしていくだろうと考える。

なお、本事業は平成29年度も継続が決定したの で、今年度も、本システムの充実に努めたい。

参考文献

1）足と靴の科学, 西脇剛史監修, pp126-129,

日刊工業新聞社，2013

2）足部スポーツ障害治療の科学的基礎, pp21-41, 服林徹, 蒲田和芳監修, 有限会社ナッ プ, 2012 